\title{
During winter the body resists insulin
}

\author{
Timo Partonen \\ Hypertension Research (2013) 36, 390-391; doi:10.1038/hr.2012.227; published online 24 January 2013
}

$\mathrm{M}$ etabolic syndrome has a seasonal pattern, with a higher frequency during winter. $^{1}$ It is known that the presence of metabolic syndrome can be predicted by routine fluctuations in appetite and weight, which both tend to increase during winter, and to which the relative shortage of light may contribute. ${ }^{2}$ Now, in this issue of Hypertension Research, Kamezaki et al. ${ }^{3}$ demonstrate that the prevalence of metabolic syndrome increases by $4.2 \%$ during winter compared with during summer. They further report that this increase is mainly owing to the elevated blood pressure and blood glucose levels that are more prevalent among a population during winter. This work is a logical continuation of their earlier findings in which they described a seasonal variation in the prevalence of metabolic syndrome.

One is left with the question of why blood pressure and fasting blood glucose levels tend to increase during winter? A key here might be visceral fat accumulation, as it is known to have a central role in the development of metabolic syndrome. A recent study has demonstrated that the transcription of genes related to circadian rhythm, inflammation and oxidative stress is associated with visceral fat accumulation. ${ }^{4}$ Among these genes are the circadian clock genes PER1, CLOCK and CRY2, whose expression in blood cells correlates with the estimated visceral fat area. Earlier studies have elucidated the relationships between the clock gene variants and metabolic syndrome. Variants of the core circadian clock gene ARNTL bear susceptibility to type 2 diabetes and hypertension. ${ }^{5}$ CRY2 variants and CRY1 variants have associations with type 2

$\mathrm{T}$ Partonen is at National Institute for Health and Welfare, Department of Mental Health and Substance Abuse Services, Helsinki, Finland

E-mail: timo.partonen@thl.fi diabetes. ${ }^{6}$ Of the risk factors for metabolic syndrome, hypertension and high-fasting blood glucose levels are associated with variants of NPAS2 (similar to CLOCK) and with those of PER2, respectively. ${ }^{7}$

Proteins encoded from CRY2 and CRY1 are of particular interest, as these proteins are the actual repressors of the key activators (CLOCK, NPAS2, ARNTL, ARNTL2) of the circadian clock and their dimerizationinduced transcriptional complexes. ${ }^{8,9}$ Here, if the repressive feedback loops of both CRY1 and CRY2 are intact, the nuclear ratio of CRY1 to CRY2 controls the period of the circadian clock, where more CRY1 causes longer periods and more CRY2 causes shorter periods. ${ }^{10}$ Deficiencies in CRY2 and CRY1 have been suggested in one study to cause elevations in circulating glucocorticoid levels and to impair glucose tolerance, ${ }^{11}$ and have been suggested in another study to cause elevated secretion of pro-inflammatory cytokines and to increase susceptibility to chronic inflammation. ${ }^{12}$ Such physiological responses are likely to contribute to visceral fat accumulation.

A key to the seasonal variation in the prevalence of metabolic syndrome might lie in understanding the strength of the interaction of CRY2 with PER2, ${ }^{13}$ and in the identification of small molecule activators of CRY2. ${ }^{10}$ In day-active animals, the morning-active cells set the timing of the circadian cellular network and adjust behavior during winter, whereas the eveningactive cells dominate during summer. ${ }^{14}$ Further, it is the interactions of CRY2 and CRY1 (for which expression peaks early in the night) with PER2 and PER1 (for which expression peaks during the day) that produces the control of a summer or winter physiology. ${ }^{15}$ As regards metabolic syndrome, not only known mechanisms of visceral fat accumulation but also the activity of brown adipose tissue are of interest in terms of adaptation to habitat and seasonal variation in weight. ${ }^{16}$ Beyond visceral white adipocytes, brown adipose tissue and the roles of CRY2 and CRY1 in brown adipocytes should not be ignored, but they remain to be tested. ${ }^{17}$

From the clinical point of view, there is now more evidence to show that paying attention to the season when a health check-up takes place is relevant. Here, the assessment of seasonal variations in appetite and weight may be particularly helpful in screening those at risk of metabolic syndrome.

1 Kamezaki F, Sonoda S, Tomotsune Y, Yunaka H, Otsuj Y. Seasonal variation in metabolic syndrome prevalence. Hypertens Res 2010; 33: 568-572.

2 Grimaldi S, Englund A, Partonen T, Haukka J, Pirkola $S$, Reunanen A, Aromaa A, Lönnqvist J. Experienced poor lighting contributes to the seasonal fluctuations in weight and appetite that relate to the metabolic syndrome. J Environ Public Health 2009; 2009: 165013.

3 Kamezaki F, Sonoda S, Nakata S, Muraoka Y, Okazaki M, Tamura M, Abe H, Tekeuchi M, Otsuji Y. Association of seasonal variation in the prevalence of metabolic syndrome with insulin resistance. Hypertens Res 2013; 36: 398-402.

4 Yamaoka M, Maeda N, Nakamura S, Kashine S, Nakagawa Y, Hiuge-Shimizu A, Okita K, Imagawa A, Matsuzawa Y, Matsubara K, Funahashi T, Shimomura I. A pilot investigation of visceral fat adiposity and gene expression profile in peripheral blood cells. PLOS ONE 2012; 7: e47377.

5 Woon PY, Kaisaki PJ, Bragança J, Bihoreau MT, Levy JC, Farrall M, Gauguier D. Aryl hydrocarbon receptor nuclear translocator-like (BMAL1) is associated with susceptibility to hypertension and type 2 diabetes. Proc Natl Acad Sci USA 2007; 104: 14412-14417.

6 Kelly MA, Rees SD, Hydrie MZ, Shera AS, Bellary S, O'Hare JP, Kumar S, Taheri S, Basit A, Barnett AH. DIAGRAM Consortium; SAT2D Consortium. Circadian gene variants and susceptibility to type 2 diabetes: a pilot study. PLoS ONE 2012; 7: e32670.

7 Englund A, Kovanen L, Saarikoski ST, Haukka J, Reunanen A, Aromaa A, Lönnqvist J, Partonen T. NPAS2 and PER2 are linked to risk factors of the metabolic syndrome. J Circadian Rhythms 2009; 7: 5 .

8 Dardente H, Fortier EE, Martineau V, Cermakian N. Cryptochromes impair phosphorylation of transcriptional 
activators in the clock: a general mechanism for circadian repression. Biochem J 2007; 402: 525-536.

9 Ye R, Selby CP, Ozturk N, Annayev Y, Sancar A. Biochemical analysis of the canonical model for the mammalian circadian clock. J Biol Chem 2011; 286: 25891-25902.

10 Hirota T, Lee St JW, John PC, Sawa M, Iwaisako K, Noguchi T, Pongsawakul PY, Sonntag T, Welsh DK, Brenner DA, Doyle 3rd FJ, Schultz PG, Kay SA. Identification of small molecule activators of cryptochrome. Science 2012; 337: 1094-1097.

11 Lamia KA, Papp SJ, Yu RT, Barish GD, Uhlenhaut NH Jonker JW, Downes M, Evans RM. Cryptochromes mediate rhythmic repression of the glucocorticoid receptor. Nature 2011; 480: 552-556.

12 Narasimamurthy R, Hatori M, Nayak SK, Liu F, Panda S, Verma IM. Circadian clock protein cryptochrome regulates the expression of proinflammatory cytokines. Proc Natl Acad Sci USA 2012; 109: 12662-12667.

13 Schneider K, Köcher T, Andersin T, Kurzchalia T, Schibler U, Gatfield D. CAVIN-3 regulates circadian period length and PER:CRY protein abundance and interactions. EMBO Rep 2012; 13: 1138-1144.

14 Stoleru D, Nawathean P, Fernández MP, Menet JS, Ceriani MF, Rosbash M. The Drosophila circadian network is a seasonal timer. Cell 2007; 129: 207-219.
15 Lincoln G, Messager S, Andersson H, Hazlerigg D. Temporal expression of seven clock genes in the suprachiasmatic nucleus and the pars tuberalis of the sheep: evidence for an internal coincidence timer. Proc Natl Acad Sci USA 2002; 99: 13890-13895.

16 Hancock AM, Witonsky DB, Alkorta-Aranburu G, Beall $\mathrm{CM}$, Gebremedhin A, Sukernik R, Utermann G, Pritchard JK, Coop G, Di Rienzo A. Adaptations to climate-mediated selective pressures in humans. PLoS Genet 2011; 7: e1001375.

17 Partonen T. Hypothesis: cryptochromes and brown fat are essential for adaptation and affect mood and moodrelated behaviors. Front Neurol 2012; 3: 157. 